\title{
Serial:Powerpoint Presentasi:
}

\section{MENGENAL KAWASAN KARST, CI RI -CI RI DAN TI NDAKAN PREVENTIV SEDERHANA UNTUK PELESTARI ANNYA}

By:

Tjahyo Nugroho Adji Eko Haryono

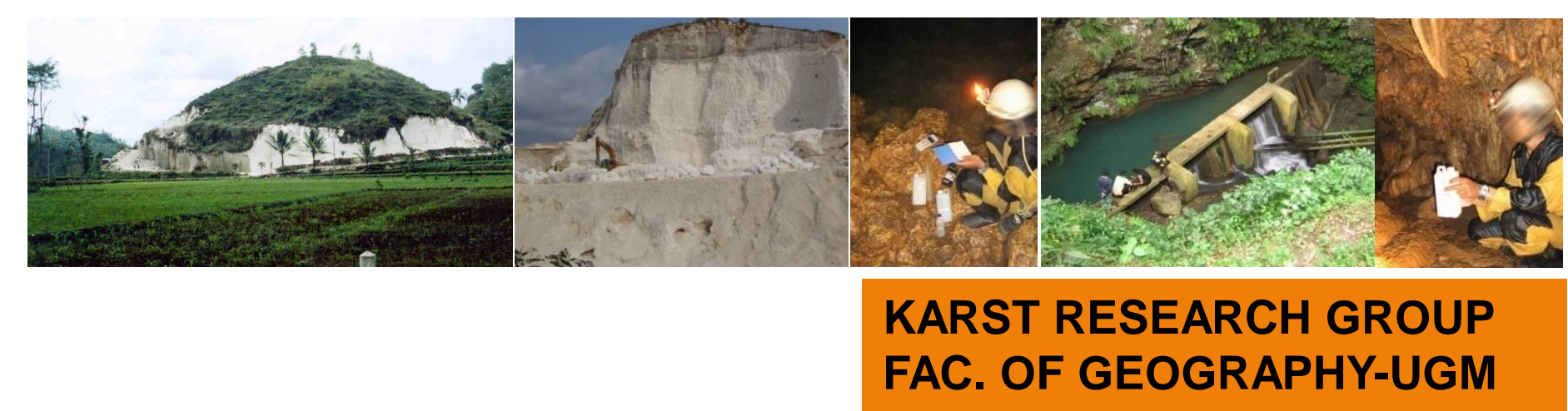




\section{Bagaimana saya tahu kalau rumahku di kawasan karst?}

Banyak terdapat gua

Terdapat bukit-bukit yang sambung menyambung

Terdapat sungai bawah tanah

Kadang terdapat telaga

Terdapat aliran sungai yang masuk ke bawah tanah 


\section{KARST GUNUNGSEWU}

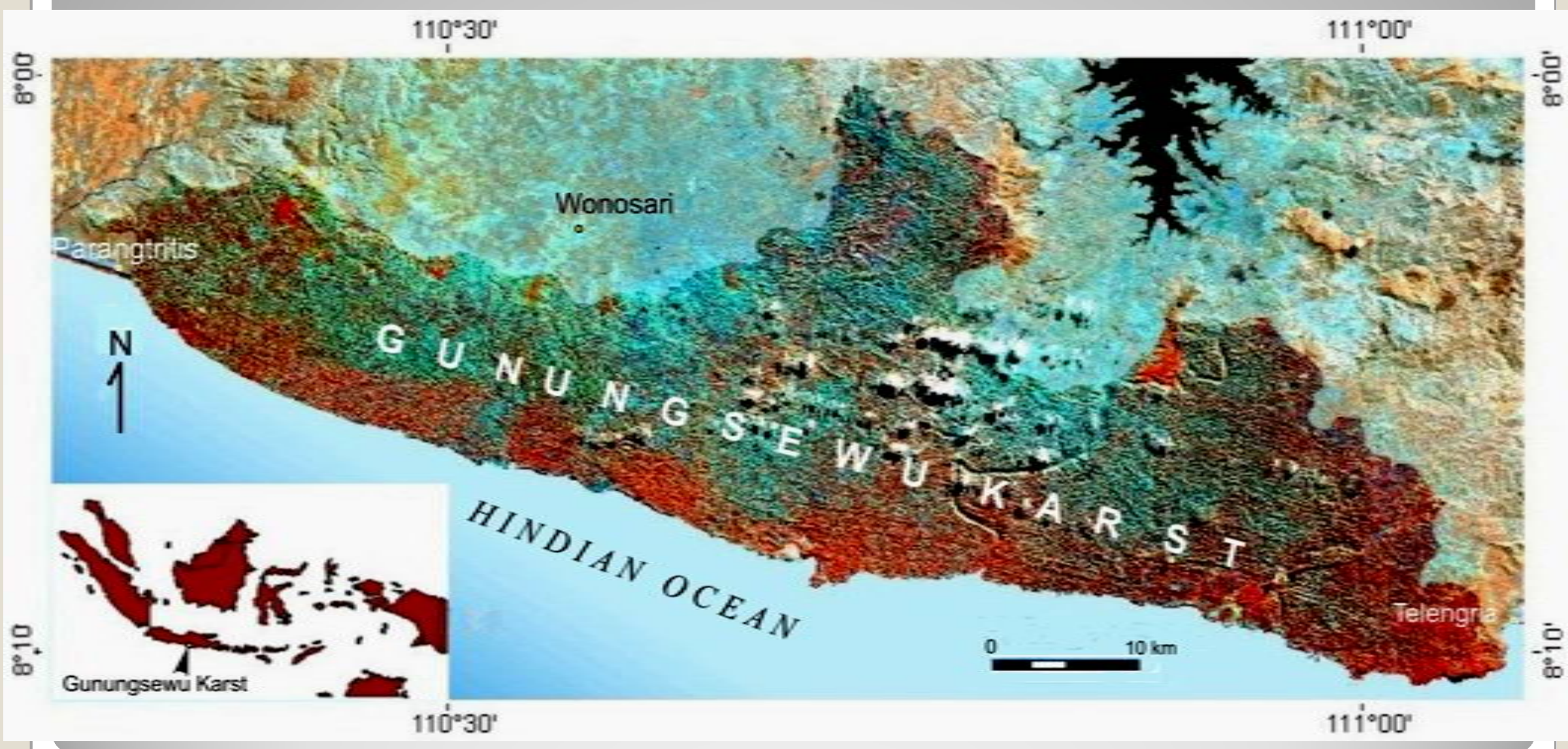


Karst Gunungsewu dari udara

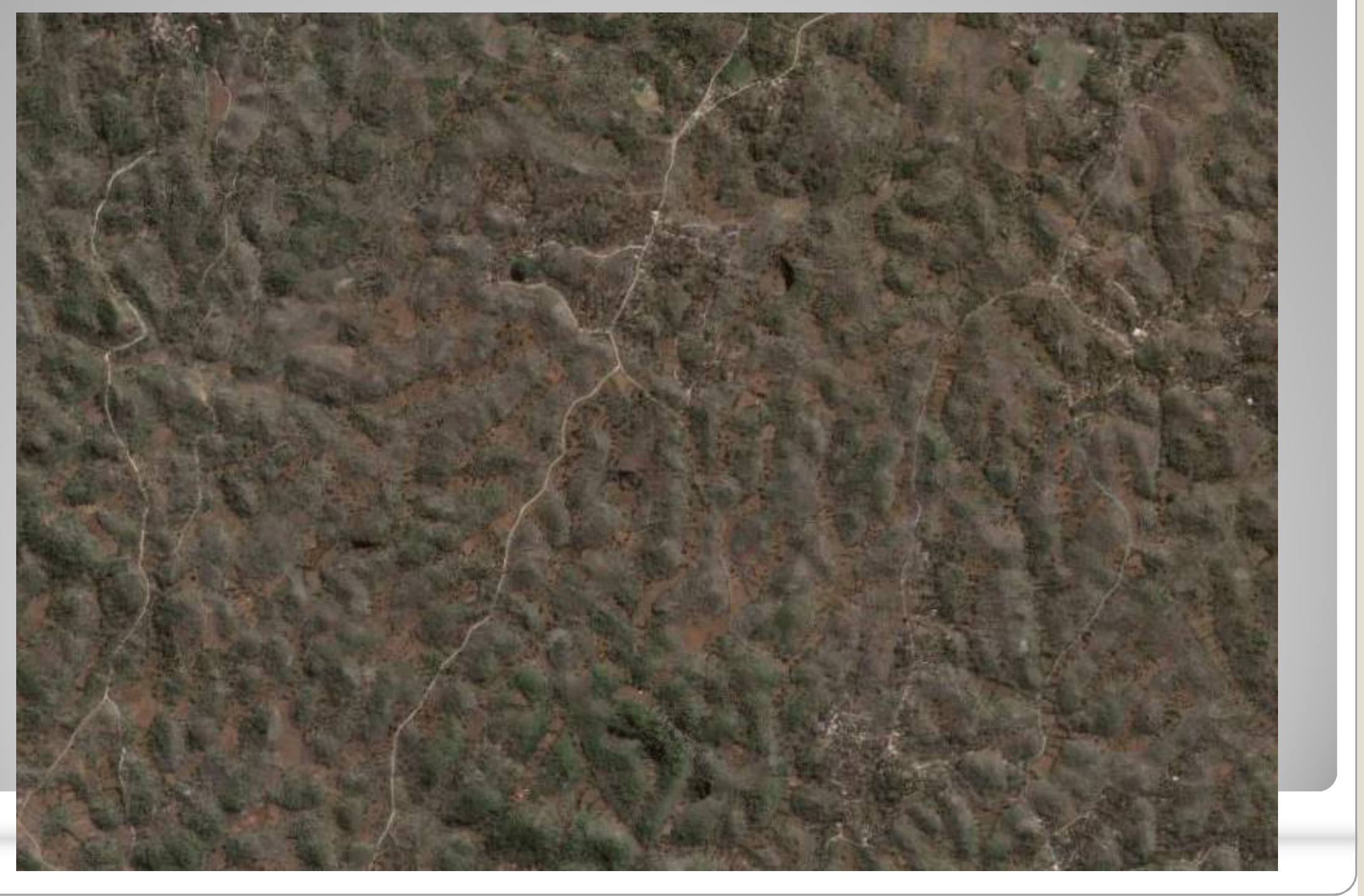




\section{Gunungsewu karst di permukaan}
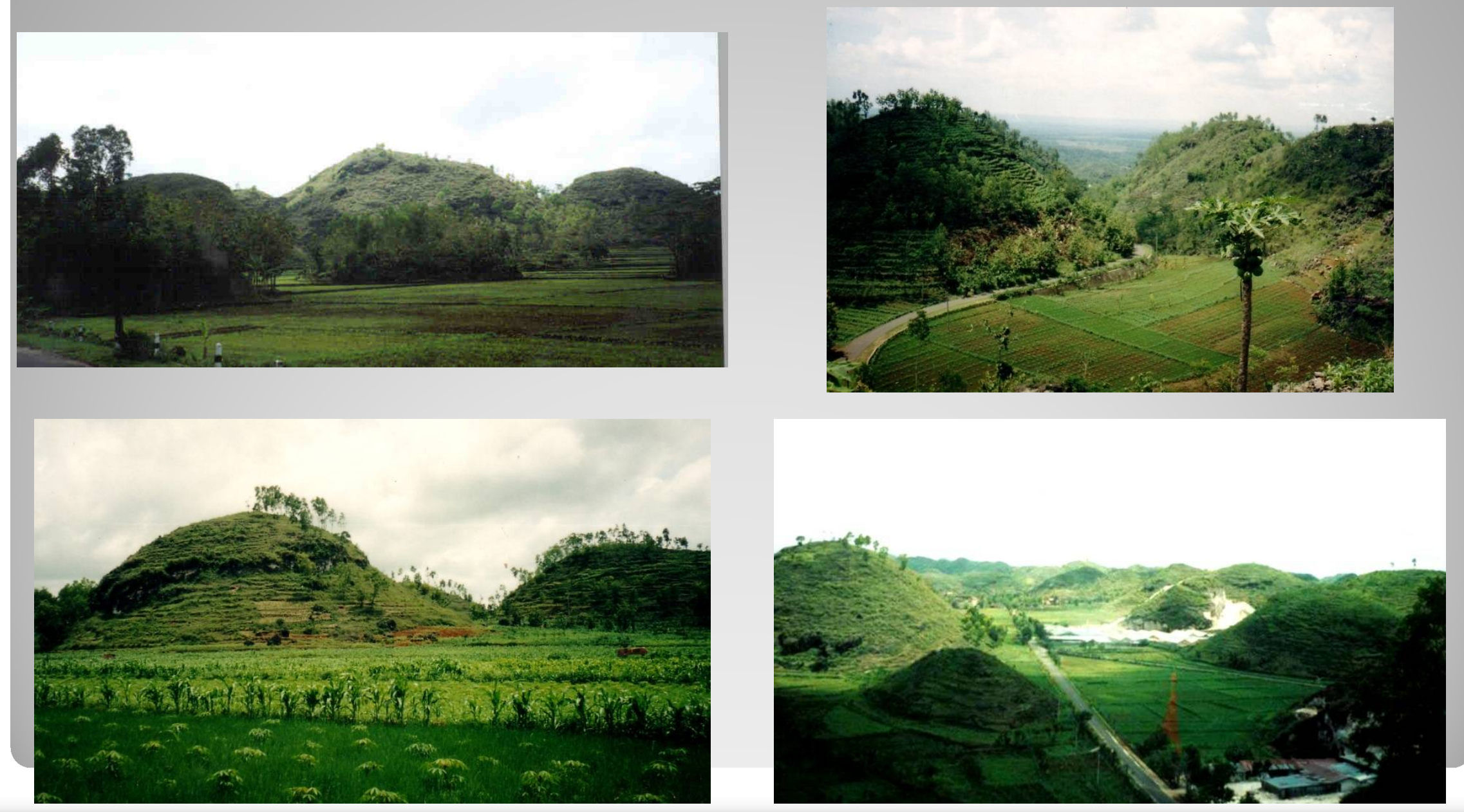


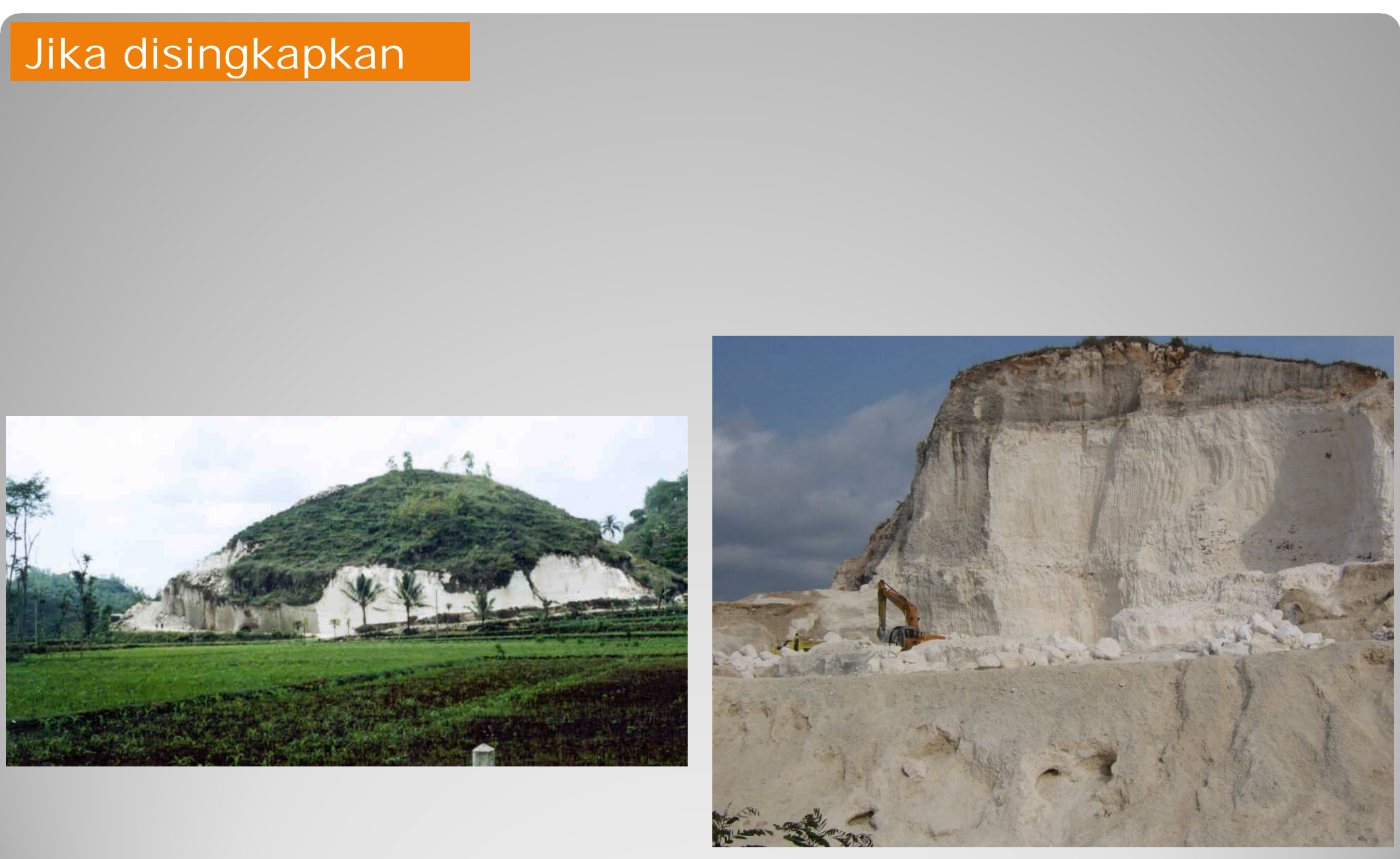




\section{Gunungsewu karst bawah permukaan}
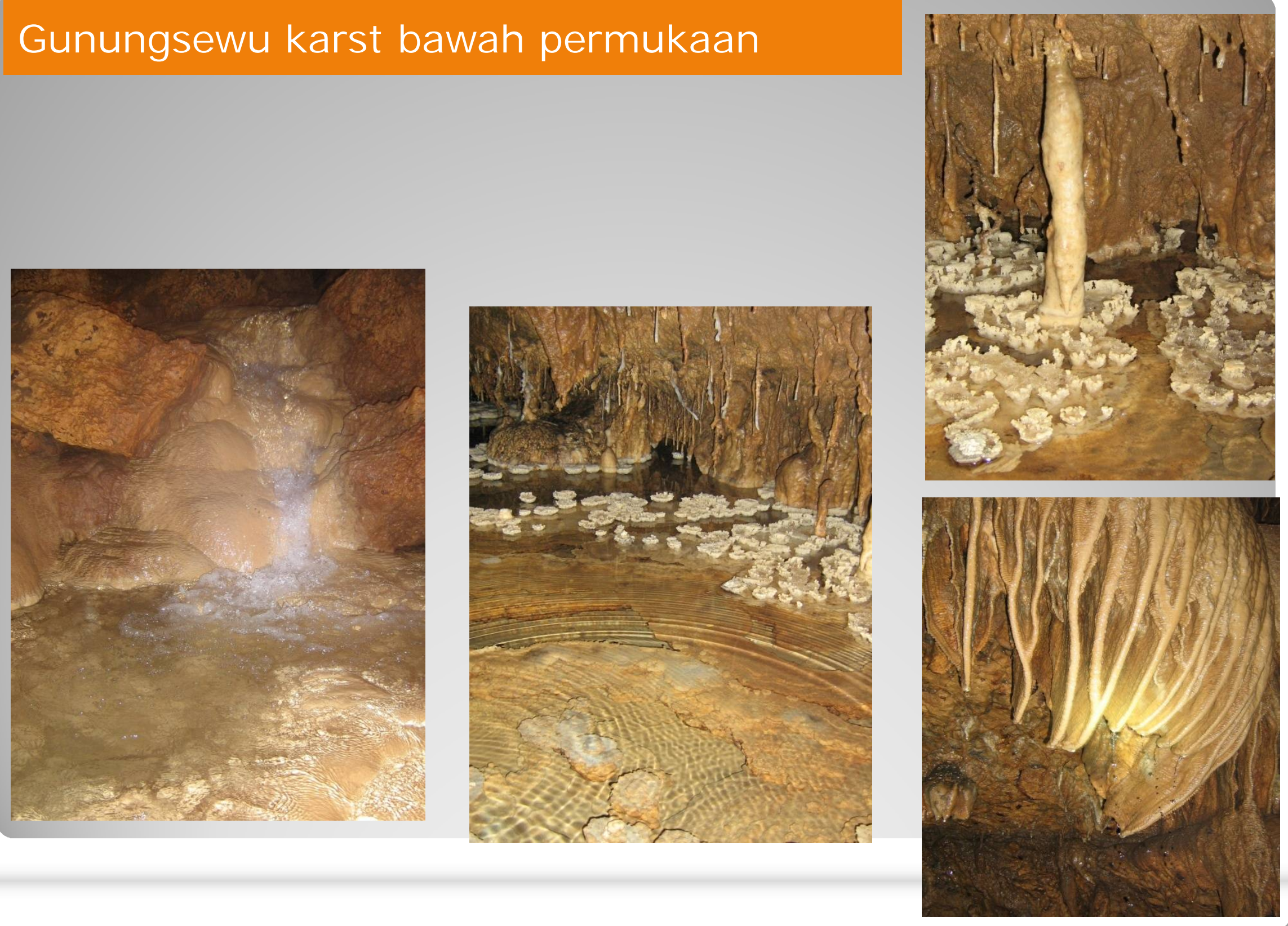


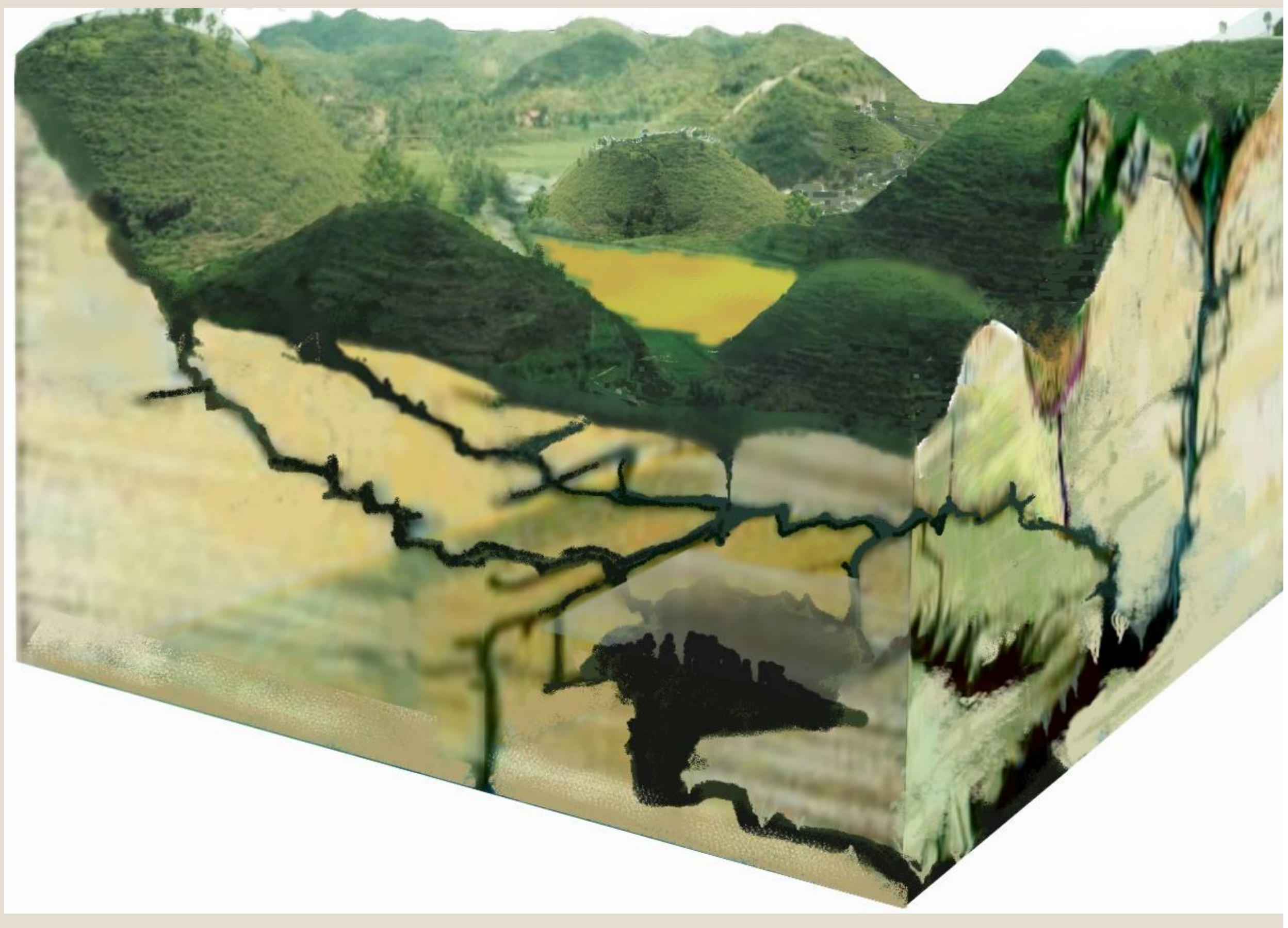




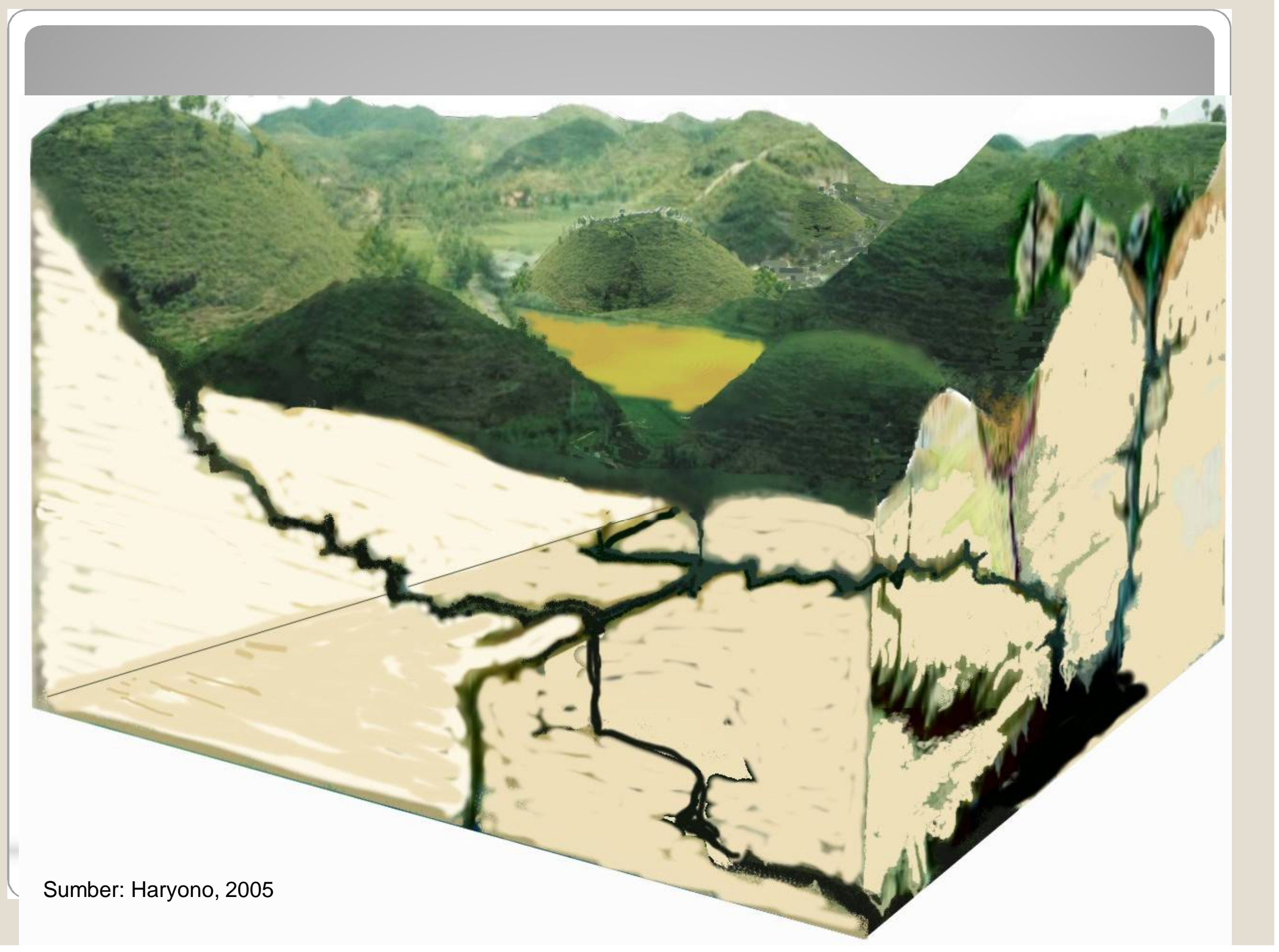



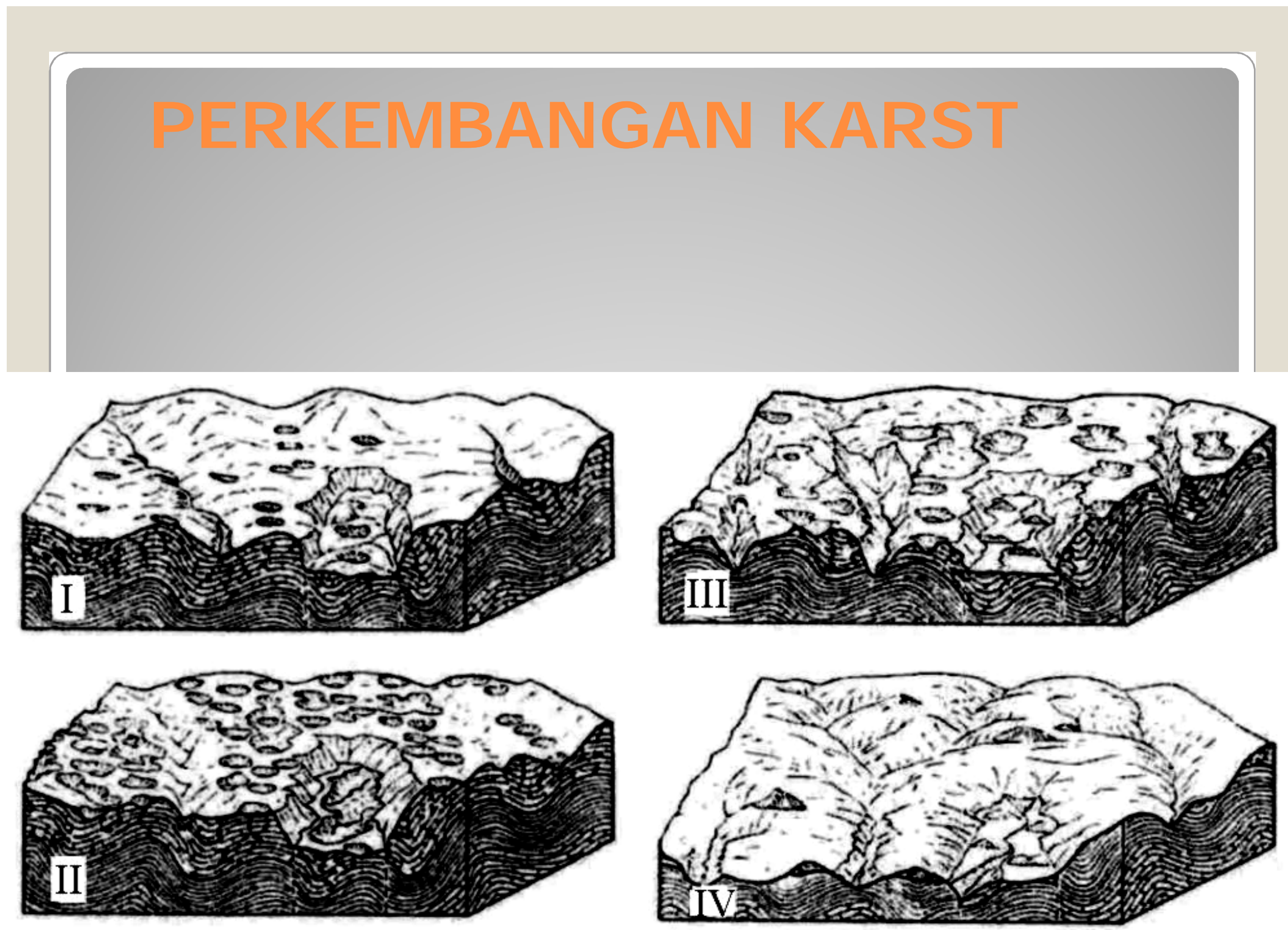


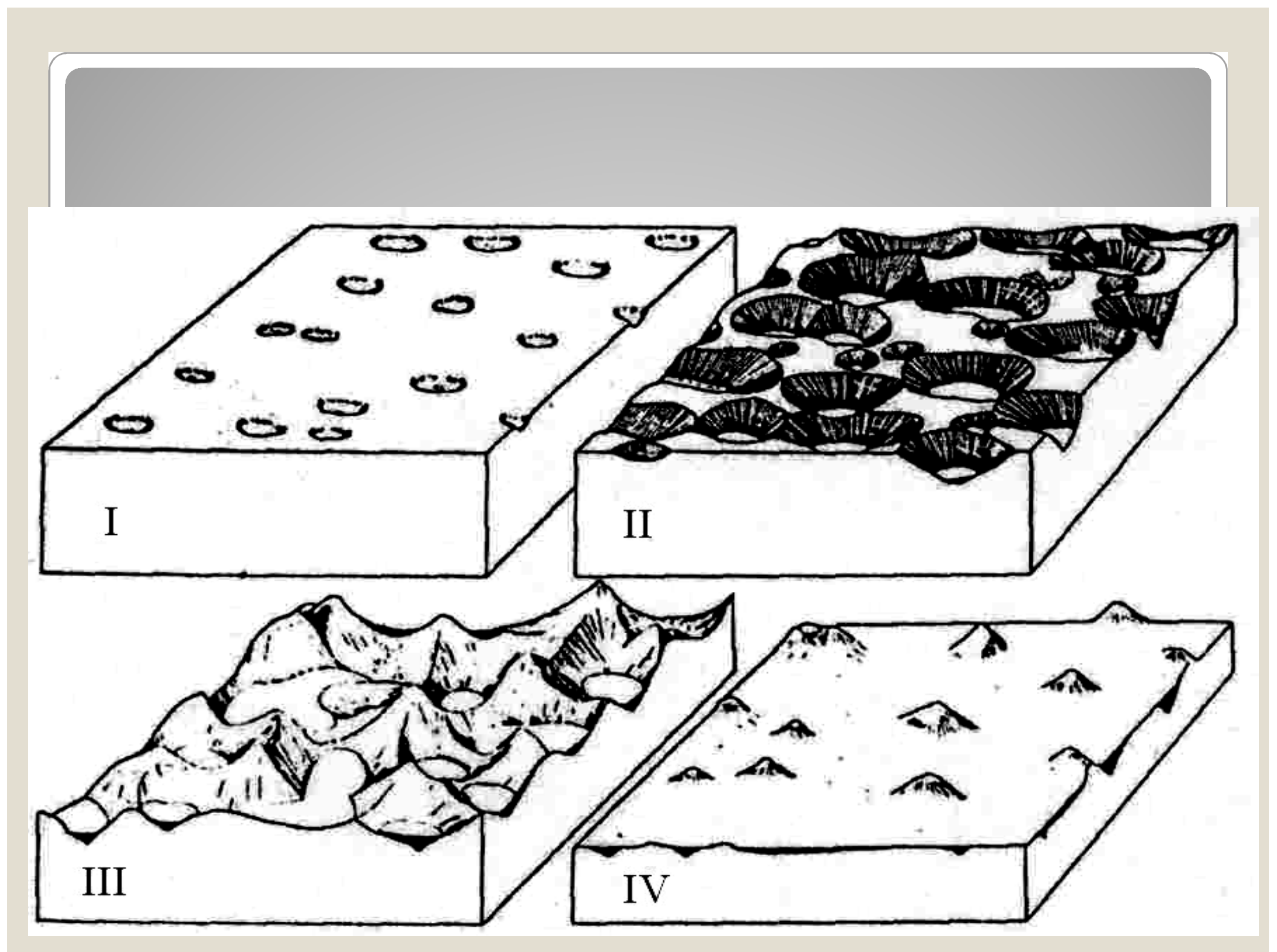



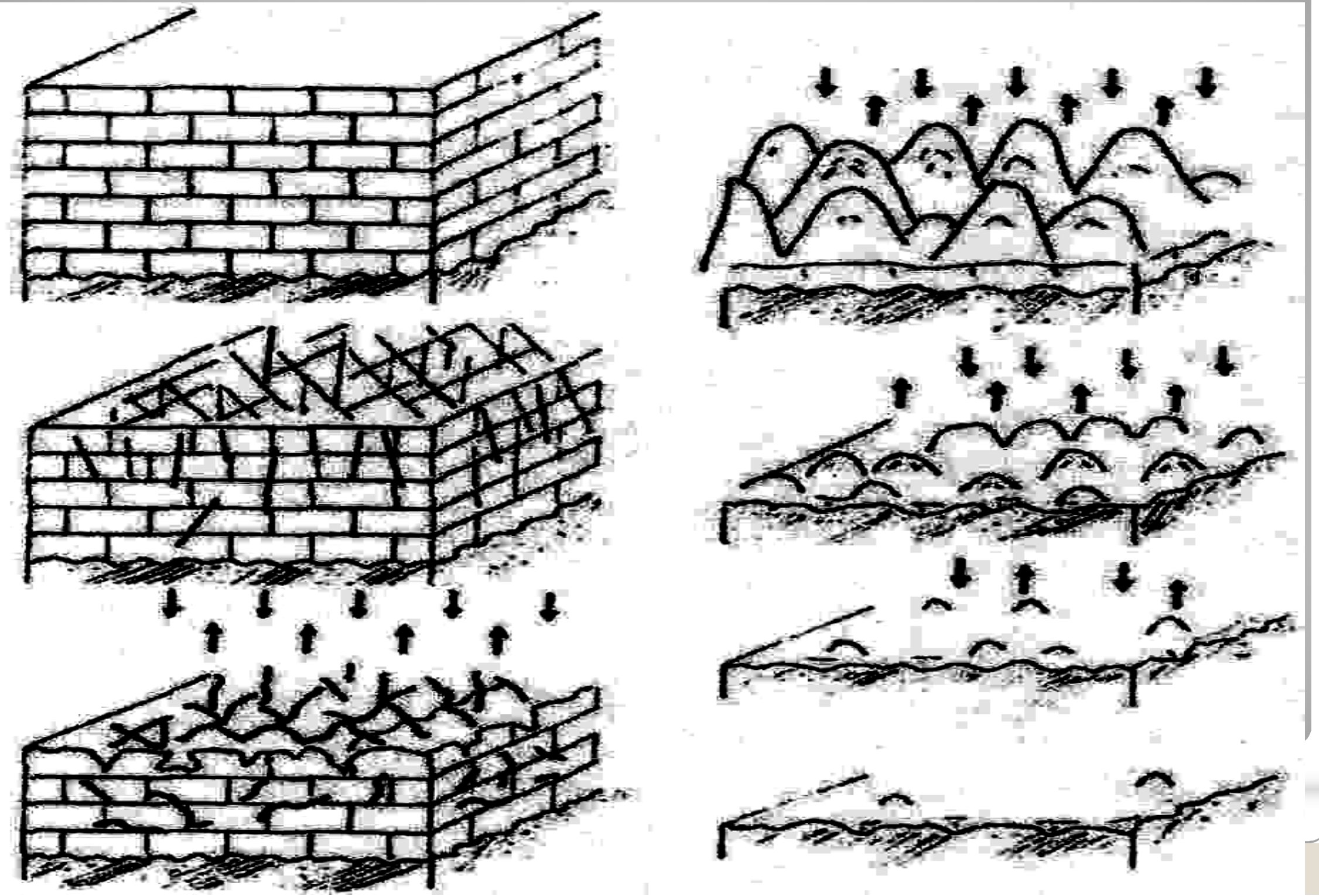


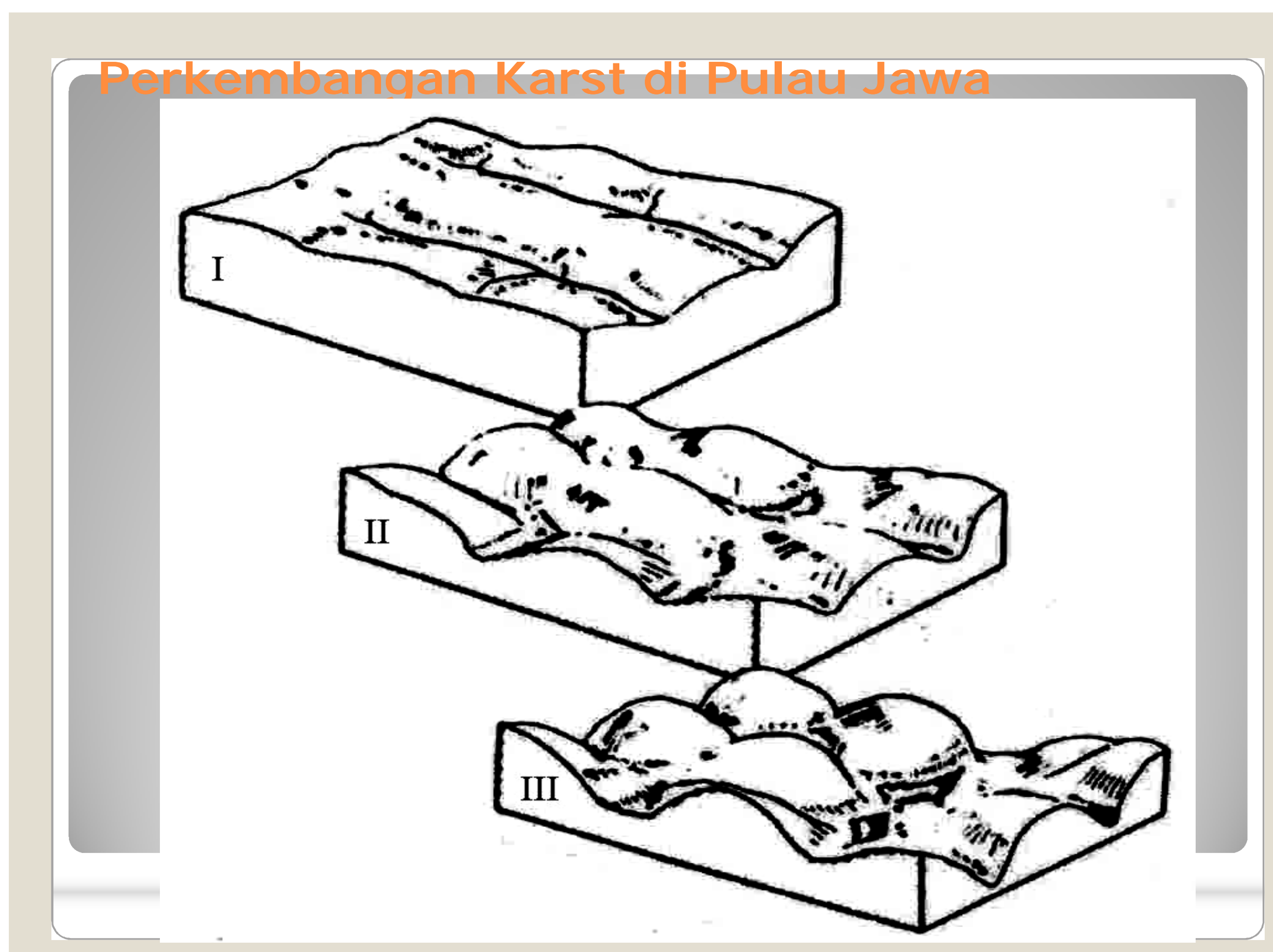




\section{TAHAP AWAL : Terendapkannya batugamping}

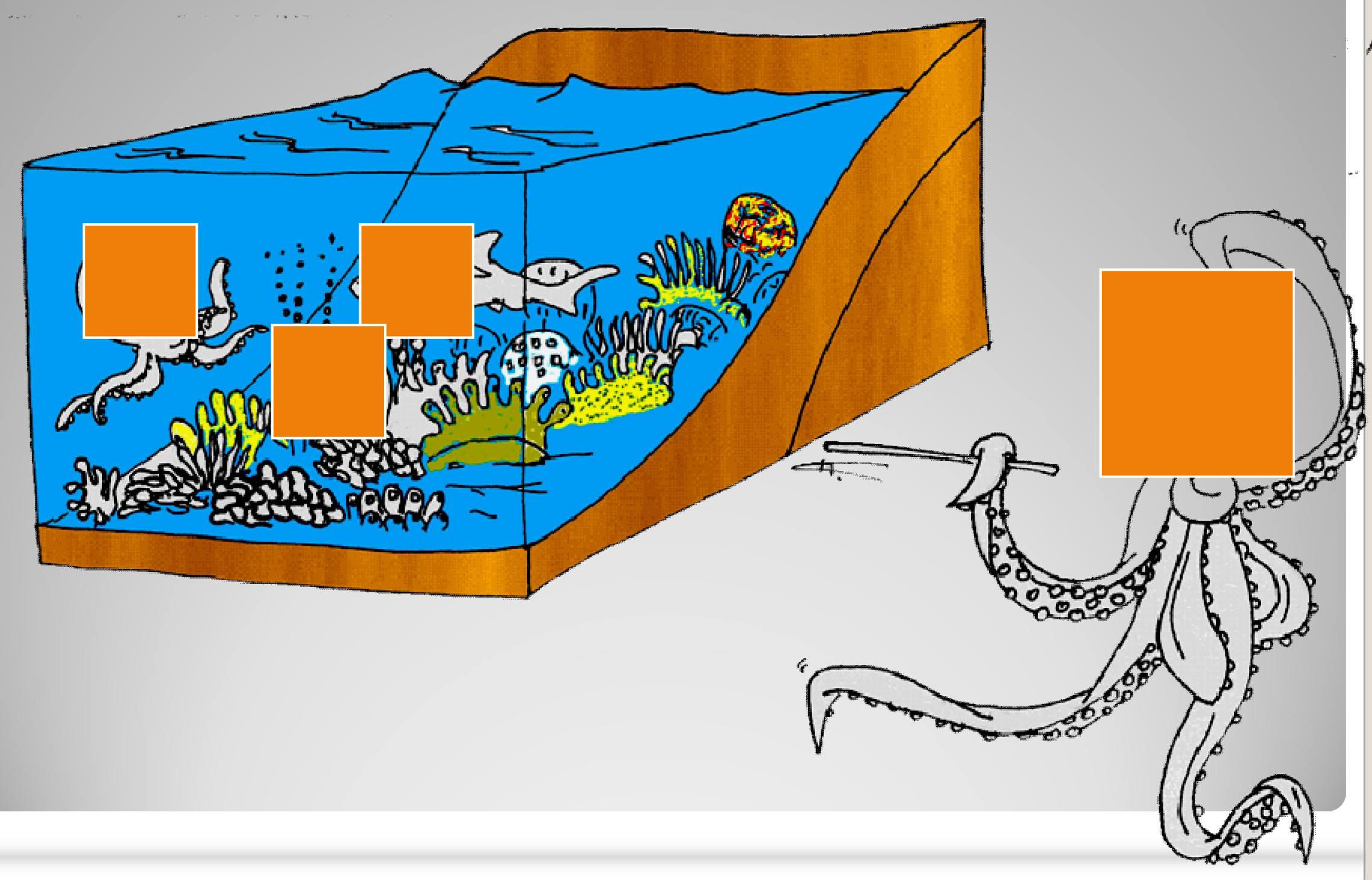


TAHAP KEDUA : Batugamping terangkat dan menjadi daratan TAHAP KETI GA: Air hujan melarutkan batugamping

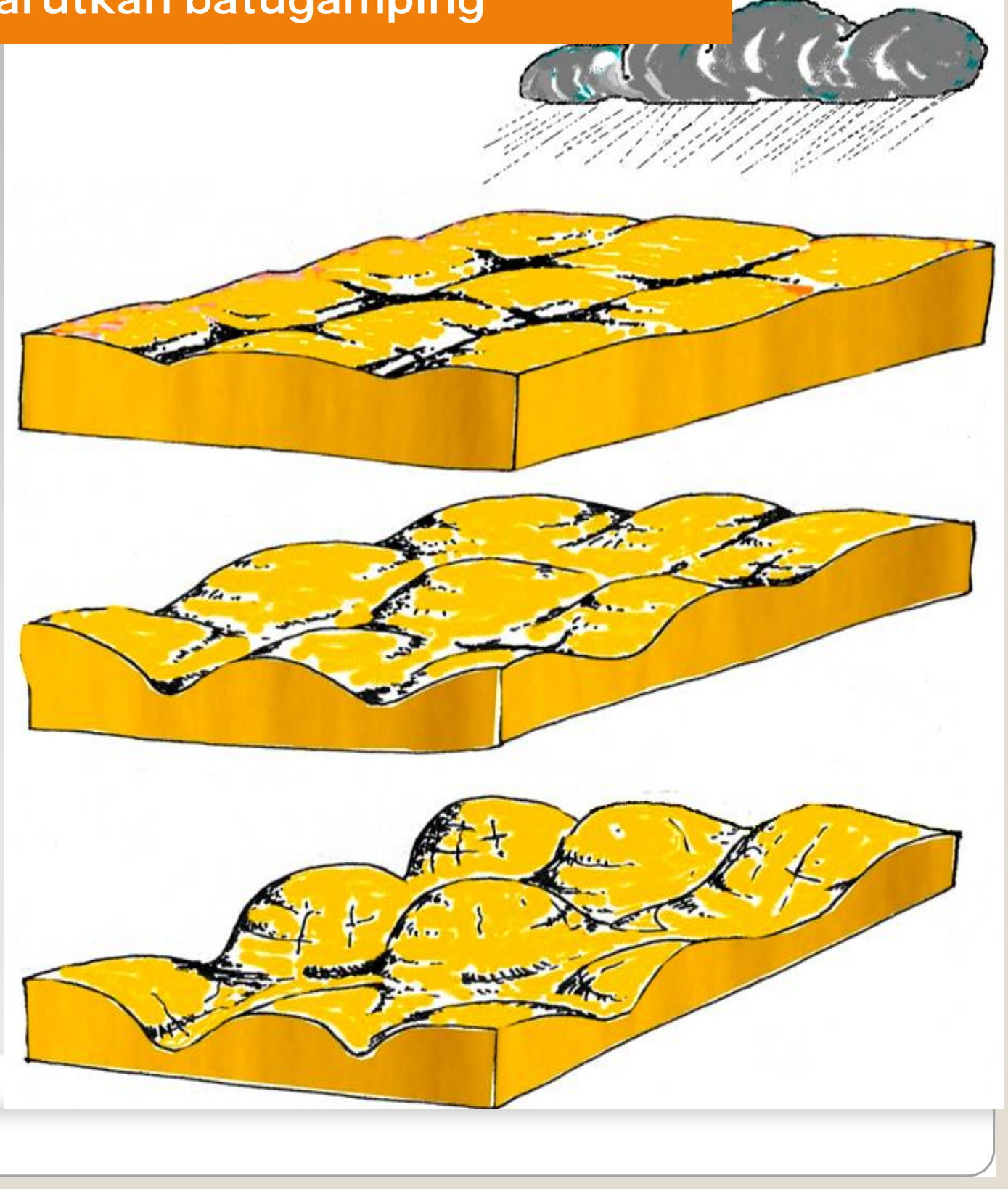




\section{Ditanahku terdapat luweng apa yang harus saya lakukan?}

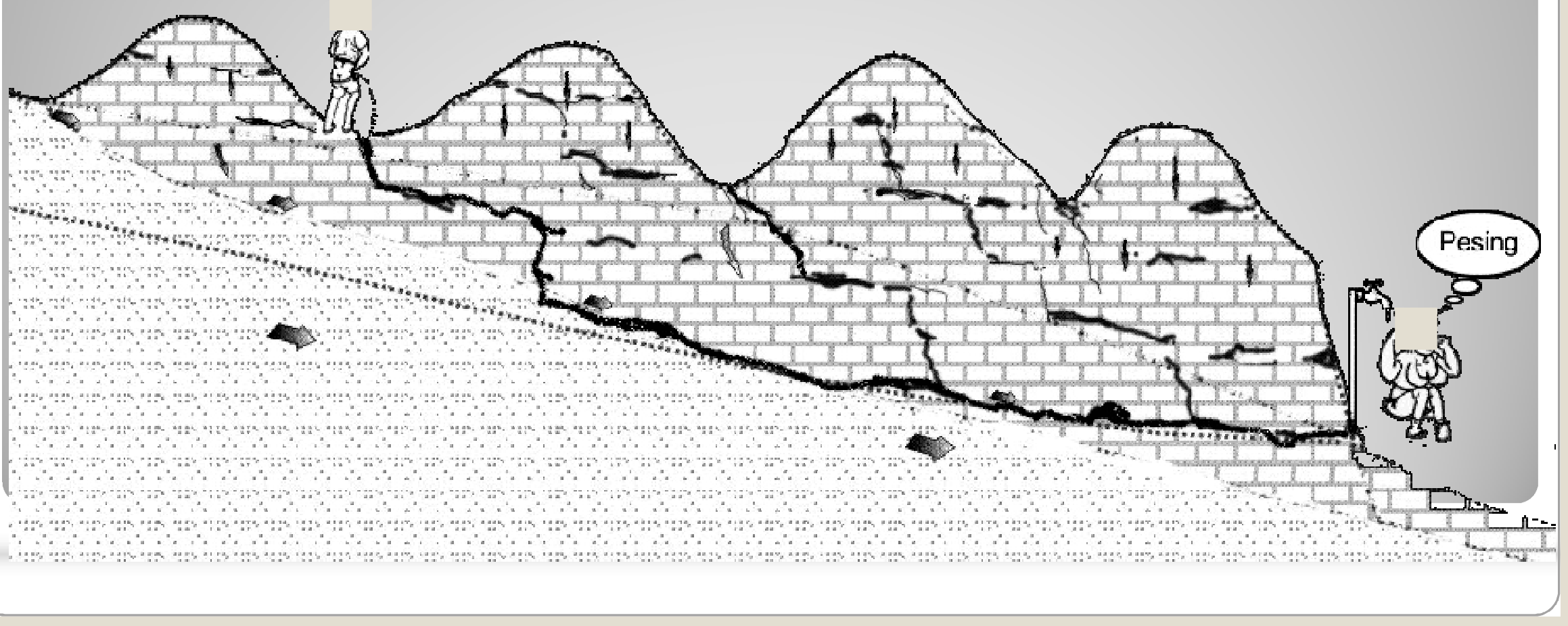




\section{Tips mengelola luweng}

Memelihara mulut luweng Mengendalikan erosi di sekitar mulut luweng dan daerah tangkapan airnya Mengendalikan penggunaan pupuk dan pestisida

Tidak menyalurkan atau membuang sampah, limbah rumah tangga, dan limbah lainnya langsung ke luweng 


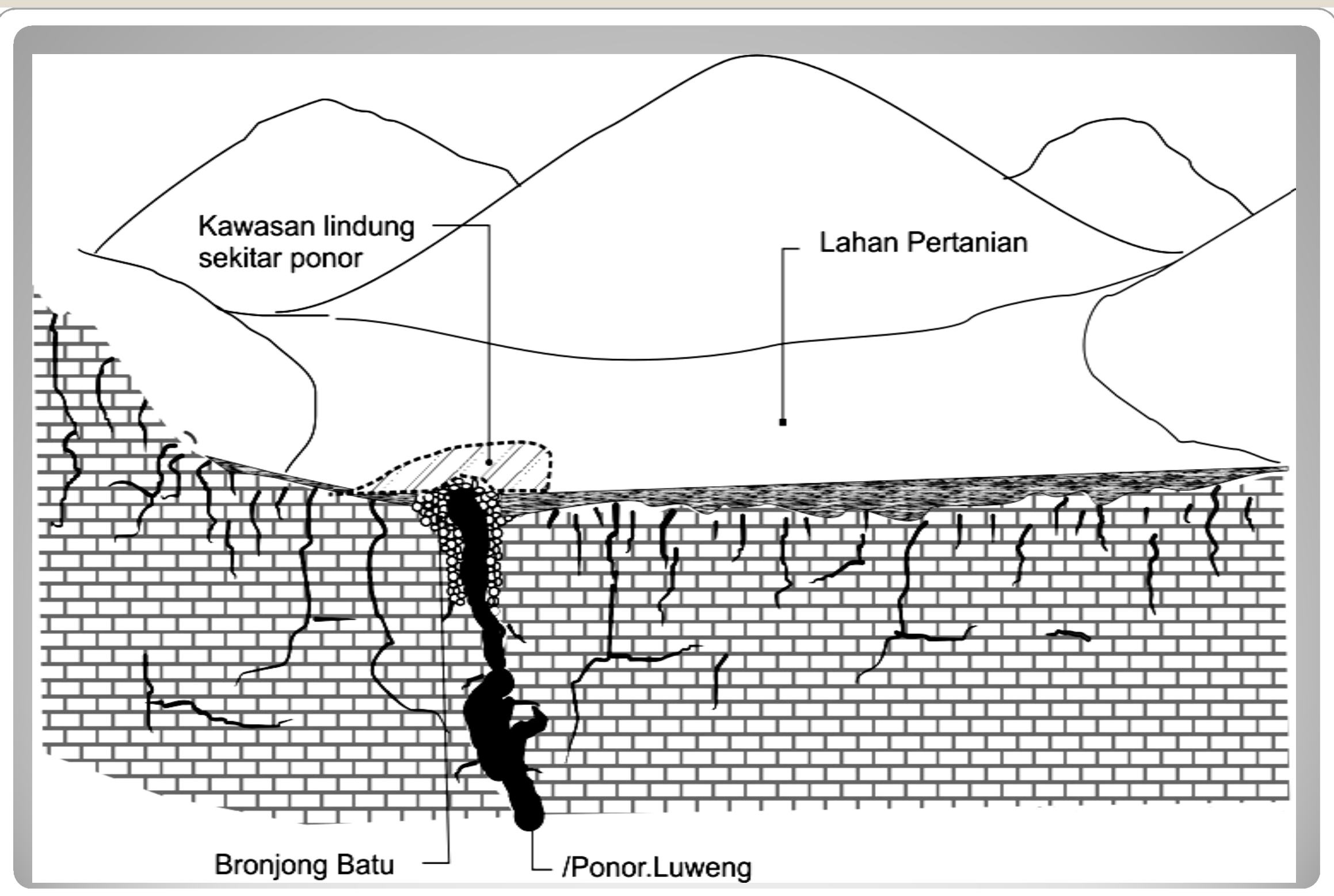




\section{Ditanahku terdapat gua, apa yang harus saya lakukan?}

Memiliki ornamen gua yang indah dan langka

Pernah menjadi hunian manusia purba Habitat/rumah satwa

Tempat masuknya sungai permukaan ke sungai bawah tanah

Tempat keluarnya sungai bawah tanah 


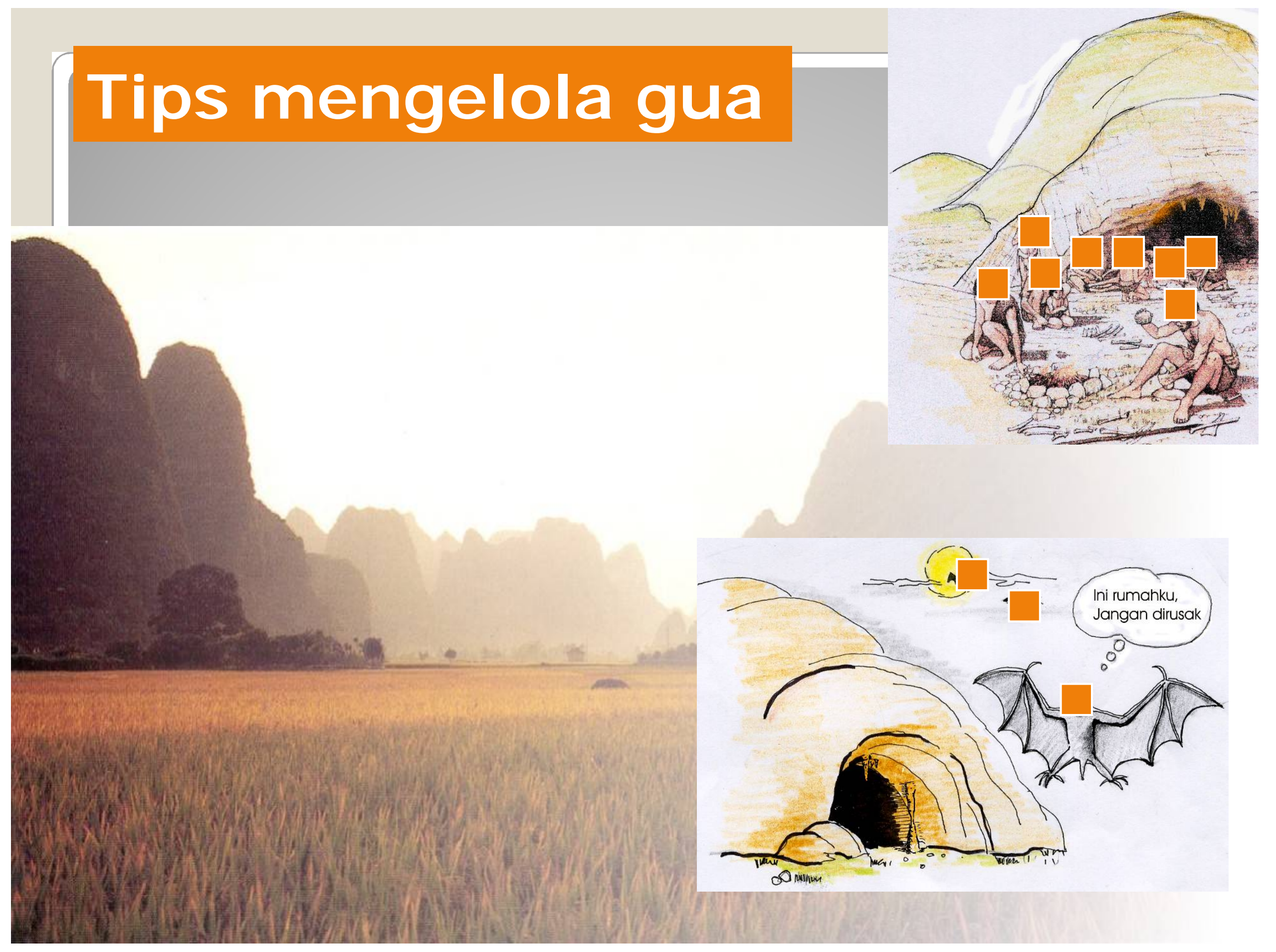


1. Untuk gua tempat masuknya sungai permukaan

- Memelihara mulut gua dari masuknya pencemar

- Mengendalikan pemanfaatan tanah di atas mulut gua/tangkapan air

2. Tidak membuang sampah, bangkai, dan limbah di dalam gua

3. Tidak menambang pospat sebelum ada rekomendasi dari dinas berwenang.

4. Ikut berpartisipasi dalam melindungi gua dengan mengontrol orang yang akan memasuki gua. 


\section{Ditanahku terdapat mataair, apa yang harus saya lakukan?}

Melindungi kawasan sekitar mataair dengan radius 50-100 meter

- Membuat bangunan penangkap mataair

- Tidak membendung mataair terlalu tinggi

\section{Bangunan penangkap mataair}

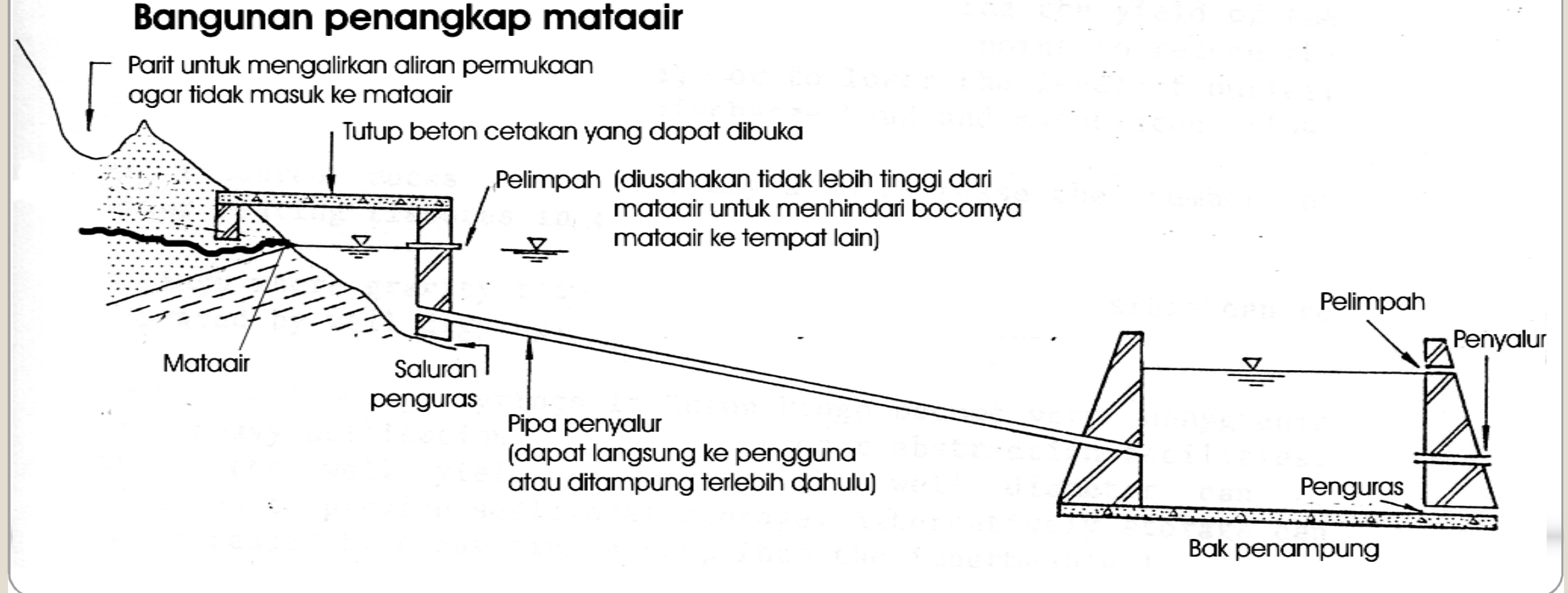




\section{Ditanahku terdapat telaga, apa yang harus saya lakukan?}

口Tidak mengeruk telaga

a Meminimalkan sedimentasi telaga

口Menjaga tepian telaga 


\section{Katanya di kawasan karst tidak boleh ditambang, apa alasannya?}

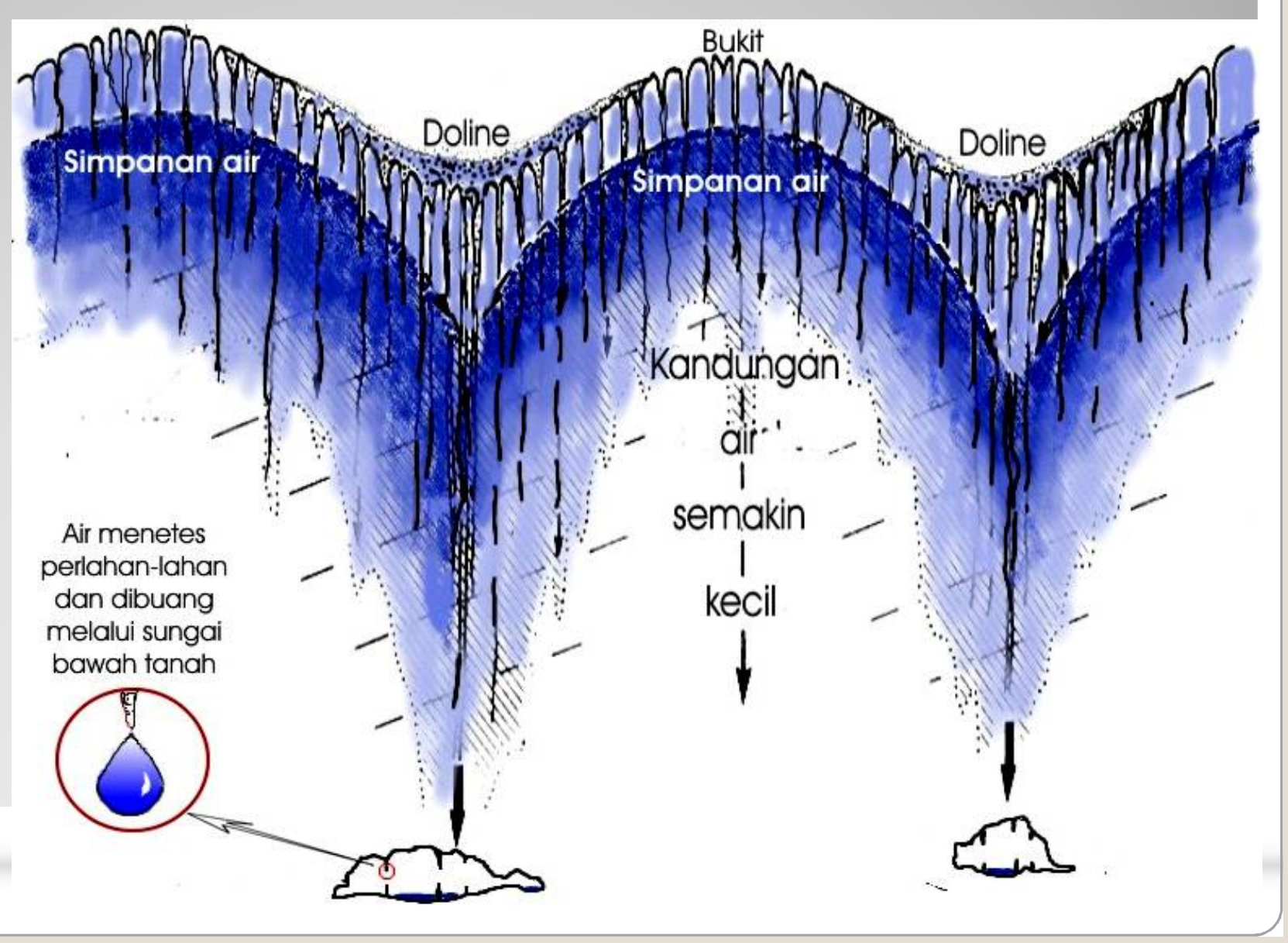




\section{Beberapa fungsi kawasan karst:}

- Bahan galian C / mineral / tambang

$\square$ Reservoir airtanah

- Penyeimbang siklus karbon, mengurangi efek rumah kaca

- Sumberdaya alami dan hayati

a Pariwisata

口 Pendidikan/penelitian

口 dll 
Still continue to research the mechanism of carbondioxide consumption in dissolution process
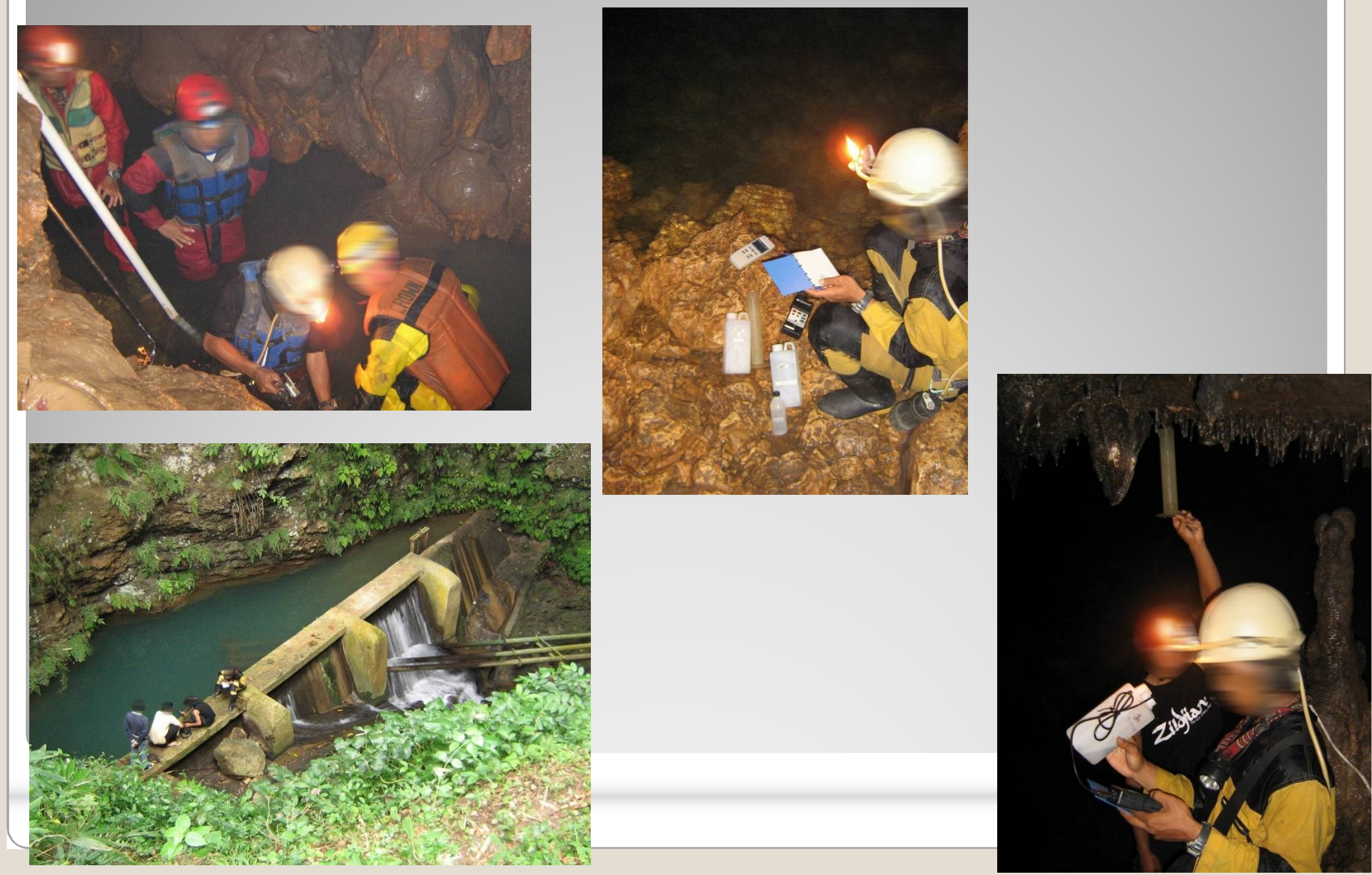


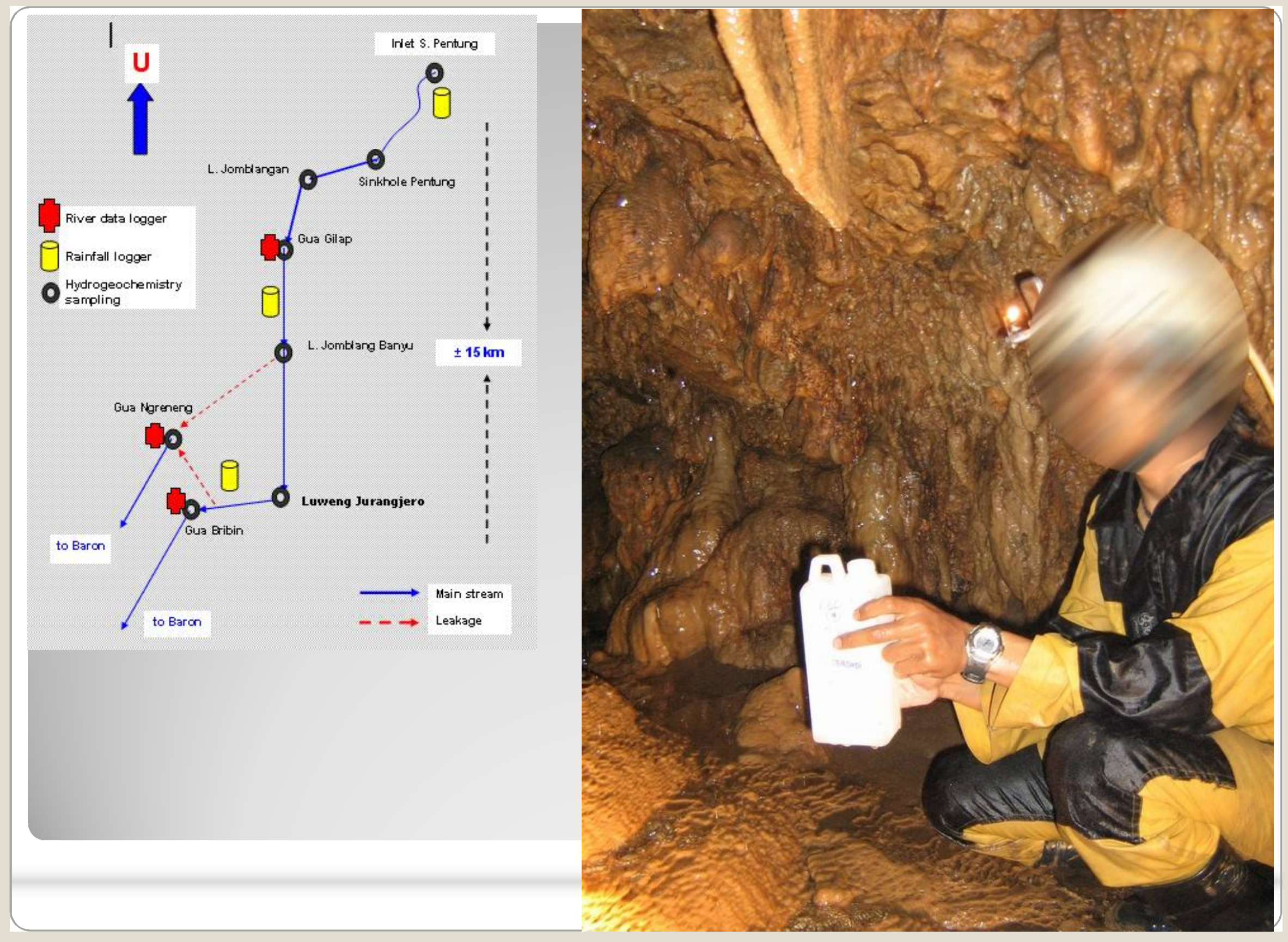




\section{Spatial and temporal variation of $\mathrm{CO}_{2}$ rest in the karst water after dissolving limestone}

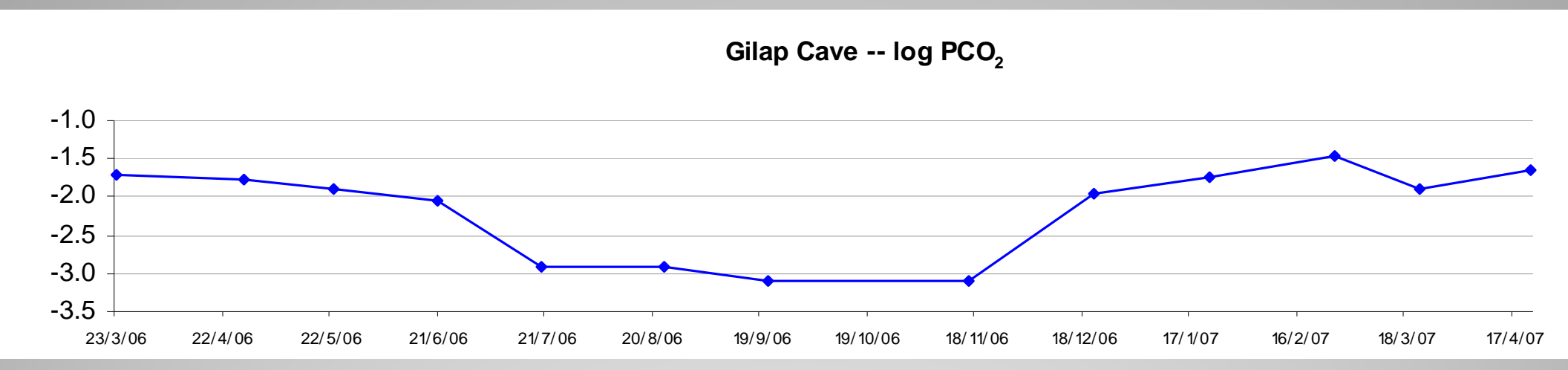

Ngreneng Cave - log $\mathrm{PCO}_{2}$
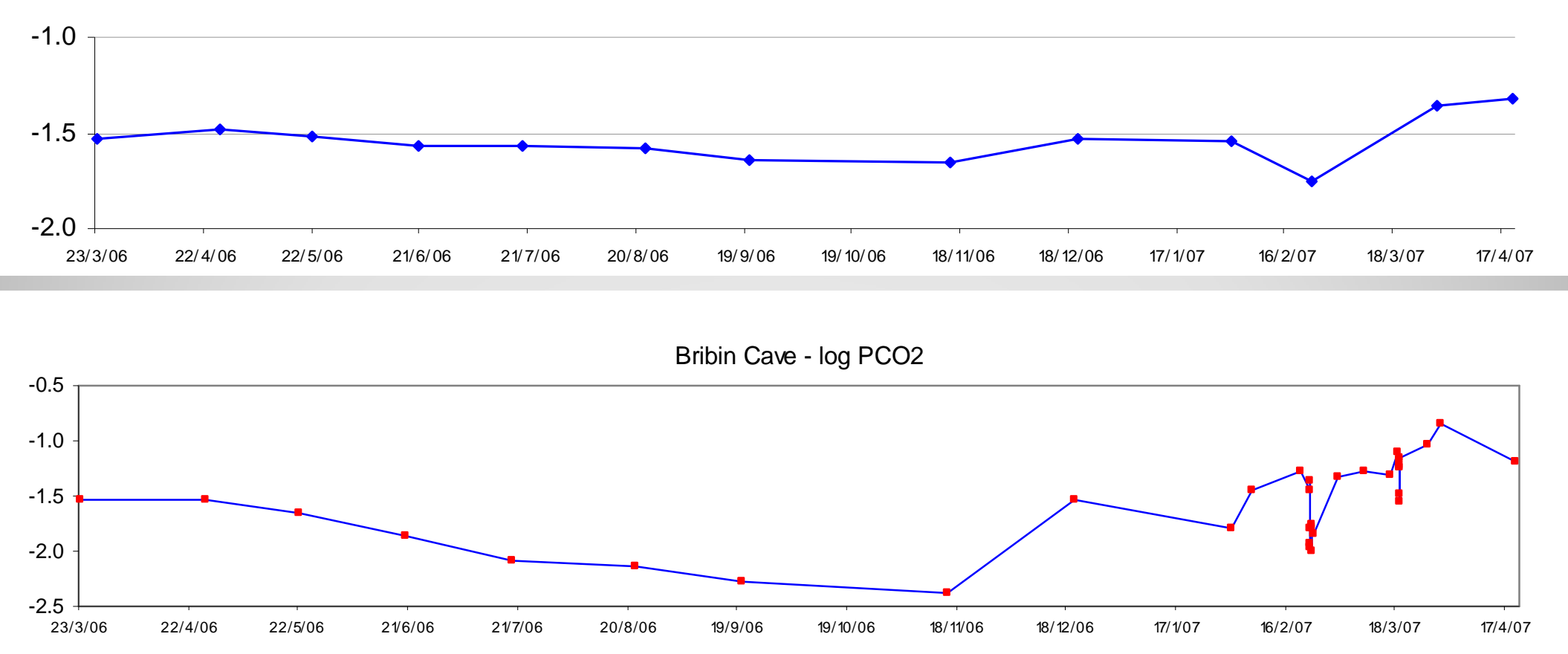